\title{
Selective Reduction of Carbonyl Compounds with $B$-Cyclohexoxydiisopinocampheylborane
}

\author{
Jin Soon Cha, "Seung Ho Jang, Sang Young Kwon, and Oh Oun Kwon \\ Depurtment of Chemistry and Institute of Natural Sciences, Yeungnam liniversity, Gyongsan 712-749, Korea \\ Recened Januay 31, 2004
}

Key Words : Selective reduction, Carbonyl compounds, $B$-Cyclohexoxydiisopinocampheylborane. Ipc ${ }_{2} B O R$, MPV type reduction

Since Brown and coworkers developed a new asymmetric reducing agent, diisopinocampheylehloroborane ( $\mathrm{Ipc}_{2} \mathrm{BCl}$ ), for prochiral ketones in 1985, 'we have investigated extensively the general reducing characteristics of diisopinocampheylhaloboranes such as $I \mathrm{pc}_{2} \mathrm{BCl}, \mathrm{Ipc}_{2} \mathrm{BBr}$ and $\mathrm{Ipc}_{2} \mathrm{BI}$ toward organic lunctional groups. Subsequently, we found that all the reagents possess a very lascinating selectivity in the reduction of carbonyl compounds. ${ }^{2}$ Soon after, we also developed other derivatives such as $A l$-hydroxy- and $A /$ alkoxydiisopinocampheylborane and found that these reagents are one of the mildest reducing agents showing an excellent selectivity in the reduction carbonyl compounds." In our continuous elfort to develop a new derivative, we prepared $B-c y c l o h e x o x y d i i s o p i n o c a m p h e y l b o r a n c\left(\mathrm{Ipc}_{2} B \mathrm{BC}_{\mathrm{hex}}\right.$ ), an alicycloalkoxy derivative, examined its reactivity toward general organic functional groups, and linally investigated its selectivity in the reduction of carbonyl compounds, in the hope of beter understanding the nature of the reagent and exploring its role in organic synthesis.

The reagent was prepared from $\alpha$-pinene by hydroboration followed by treatment with cyclohexanol in THF (Eq. I).

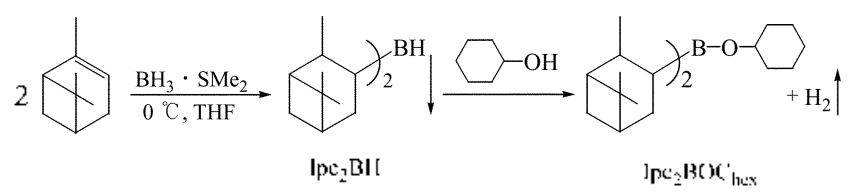

The reactivity of $\mathrm{Jpc}_{2} \mathrm{BOC}_{\mathrm{bcx}}$ toward some representative organic functional groups was examined ${ }^{4}$ and the results are summarized in lable 1 . The reagent can readily reduce a wide variety of aliphatic and aromatic aldehydes to the corresponding alcohols at $25^{\circ} \mathrm{C}$, whereas ketones are absolutely inert even in refuxing '] HF for at least 3 days. In addition, other general functional groups such as acid chlorides, esters, epoxides and nitriles, are totally inert to the reagent. Such a striking feature observed in this experiment led us investigate its chemoselectivity in the reduction of aldehydes in detail.

The selective reduction of $\alpha \beta$-unsaturated aldehydes with $\mathrm{Jpc}_{2} \mathrm{BOC}_{\mathrm{h} L \mathrm{x}}$ to the corresponding allylic alcohols was carried out and the results are summarized in lable 2 . Reduction of simple conjugated aldehydes, such as crotonaldehyde, 2hexenal and cinnamaldehyde, afforded exclusively the corresponding allylic alcohols, resulting only from 1,2-reduction.
Table 1. Reaction of Aldehydes. Ketones and Other Junctional Compounds with B-Cyclohexoxydiisopinocampheylboranc (Ipc$B O C_{\text {lex. }}$ ) in Tetrabydrofurant"

\begin{tabular}{|c|c|c|c|}
\hline \multirow{2}{*}{ Compound } & \multirow{2}{*}{$\begin{array}{l}\text { Time } \\
\text { (h) }\end{array}$} & \multicolumn{2}{|c|}{ Reduction $(\%)^{\prime \prime}$} \\
\hline & & $0^{\circ} \mathrm{C}$ & $25^{\circ} \mathrm{C}$ \\
\hline \multirow[t]{4}{*}{ hexanal } & 1 & 14 & 68 \\
\hline & 6 & 24 & 89 \\
\hline & 12 & 26 & 98 \\
\hline & 24 & 29 & 99 \\
\hline \multirow[t]{3}{*}{ cyclohexanecarboxaldchyde } & 6 & 21 & 90 \\
\hline & 12 & 28 & 100 \\
\hline & 24 & 33 & 100 \\
\hline \multirow[t]{3}{*}{ crotonaldehyde } & 3 & 12 & 90 \\
\hline & 6 & 33 & 98 \\
\hline & 12 & 41 & 99 \\
\hline \multirow[t]{4}{*}{ o-tolualdchydc } & 1 & 15 & 96 \\
\hline & 3 & 16 & 97 \\
\hline & 6 & 19 & 99 \\
\hline & 12 & 25 & 99 \\
\hline \multirow[t]{4}{*}{$p$-tolualdehyde } & 1 & 25 & 97 \\
\hline & 3 & 26 & 98 \\
\hline & 6 & 36 & 99 \\
\hline & 12 & 42 & 99 \\
\hline \multirow[t]{5}{*}{$p$-chlorobenzaldehyde } & 1 & 18 & 72 \\
\hline & 3 & 19 & 87 \\
\hline & 6 & 25 & 98 \\
\hline & 12 & 28 & 100 \\
\hline & 24 & 31 & 100 \\
\hline \multirow[t]{4}{*}{ m-hydroxybenzaldelyde } & 0.5 & 21 & 97 \\
\hline & 1 & 29 & 99 \\
\hline & 3 & 31 & 99 \\
\hline & 6 & 38 & 99 \\
\hline \multirow[t]{5}{*}{ 2-maphihaldehyde } & 1 & 16 & 74 \\
\hline & 3 & 18 & 88 \\
\hline & 6 & 19 & 98 \\
\hline & 12 & 23 & 99 \\
\hline & 24 & 29 & 99 \\
\hline \multirow[t]{2}{*}{ 2-heptanone } & 24 & 0 & $\sigma^{c}$ \\
\hline & 72 & 0 & 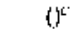 \\
\hline acetophenone & 72 & 0 & $\theta^{\circ}$ \\
\hline butyrophenone & 72 & 0 & ()$^{c}$ \\
\hline cyclohexanone & 24 & 0 & $a^{c}$ \\
\hline hexanoyl chloride & 24 & 0 & 0 \\
\hline ethyl acelate & 24 & 0 & $\theta^{c}$ \\
\hline 1.2-bulyleme oxide & 24 & 0 & 0 \\
\hline bem/onitrile & 24 & 0 & 0 \\
\hline
\end{tabular}

"Ten \% excess reagent was utilized. "GC yields. "Reacted both at $25{ }^{\circ} \mathrm{C}$ and under rellux. 
Table 2. Reduction of $\alpha \beta-1$ nnsaturated Aldehydes and Ketones

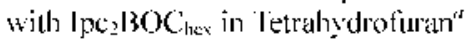

\begin{tabular}{lcrcr}
\hline Compound & $\begin{array}{c}\text { Temperature } \\
(\text { C })\end{array}$ & $\begin{array}{c}\text { Time } \\
\text { (h) }\end{array}$ & $\begin{array}{c}\text { P'roduct ratio } \\
1.2: 1.4\end{array}$ & $\begin{array}{c}\text { Yicld } \\
(\%)^{b}\end{array}$ \\
\hline crotonaldehyde & 0 & 6 & $100: 0$ & 33 \\
& & 24 & $100: 0$ & 49 \\
& 25 & 3 & $100: 0$ & 90 \\
& & 6 & $100: 0$ & 98 \\
& & 12 & $100: 0$ & 99 \\
2-hexenal & 0 & 6 & $100: 0$ & 99 \\
& & 24 & $100: 0$ & 29 \\
& 25 & 6 & $100: 0$ & 96 \\
& & 12 & $100: 0$ & 100 \\
cimnamaldehydc & 0 & 24 & $100: 0$ & 100 \\
& & 6 & $100: 0$ & 33 \\
& 25 & 3 & $100: 0$ & 43 \\
& & 6 & $100: 0$ & 97 \\
isophorome & 25 & 24 & $100: 0$ & 99 \\
chalcone & 25 & 24 & & 99 \\
\hline
\end{tabular}

"Ten \% excess teagent utilized. "Determined by GC using calibrated intertial standard.

Table 3. Competitive Reduction between Aldelydes and Ketones or Other liunctional Compounds with Ipcs $30 \mathrm{C}_{\text {thex }}$ in Terahydrofiran at $25^{\circ} \mathrm{C}^{\mathrm{ct}}$

\begin{tabular}{|c|c|c|}
\hline Starting mixture & Time (h) & $\begin{array}{l}\text { Ratio of reduction } \\
\text { products }\end{array}$ \\
\hline hexanal/2-heptanone & 24 & $100: 0$ \\
\hline hexanal acelophenone & 24 & $100: 0$ \\
\hline hexanal benzophenone & 24 & $100: 0$ \\
\hline hexanal / ben<onitrile & 24 & $100: 0$ \\
\hline hexanal / hexanoy/ chloride & 24 & $100: 0$ \\
\hline hexana] / ethyl benzoate & 24 & $100: 0$ \\
\hline ban<a]dเhyde 2-heptanone & 24 & $100: 0$ \\
\hline ben<a]dshyde / ac'stophenone & 24 & $100: 0$ \\
\hline o-tolualdehyde : 2-lueptanone & 24 & $100: 0$ \\
\hline
\end{tabular}

"Ten \% extss reagent (1.I epuiv) was utilized for the competitive reaction of" equimolar mixture of" two compounds. "Nonnalized ratio determined by $\mathrm{GC}$ with appropriate internal standard: the total yields of product alcohols were $>99.5 \%$.

The selectivity reaches $100 \%$. However, $\alpha \beta$-unsaturated ketones are absolutely inert to this reagent.

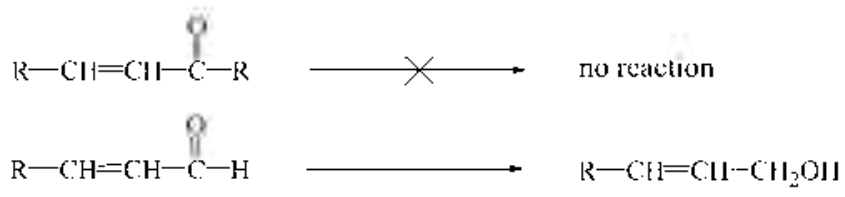

$100 \%$

As shown in lable 1 and 2 , the reagent is only reactive to aldehydes among reducible organic functional groups. Such a reactivity allows the chemoselective reduction of aldehyde function in the presence of the other functions such as ketone, acid chloride, epoxide and ester, as summarized in lable 3 . The reagent reduces only aldehydes completely to alcohols within $24 \mathrm{~h}$ at room temperature in the presence of other functional compounds. ${ }^{5}$

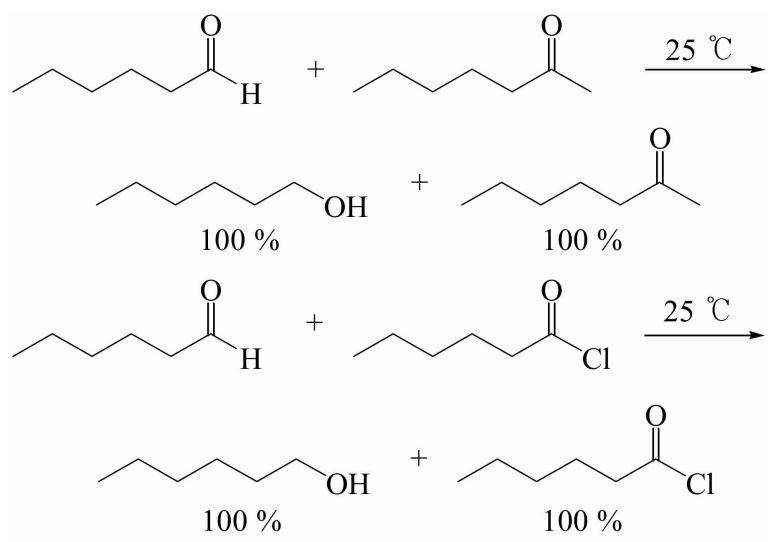

Ipc ${ }_{2} B O C_{\text {hex }}$ appears one of the Meerwein-Ponndorf-Verley (MPV) type reducing agents, which reacts only with aldehyde function. This unique reactivity of the reagent alfords the possibility for achieving a selective reduction of aldehyde function in a complex molecule.

Acknowledgment. The work was supported by KOSEF research project No. R 01-2001-00057.

\section{References and Notes}

1. (a) Chandratsekluaran. I.: Ramachandran. P. V.: [3rown. [I. C. $J$. Org. (hem. 1985. 50. 5446. (b) Brown. H. C.: Chandrasekharan. J.: Ramachandran. P. V. Hoid. 1986. 51. 3394. (c) tdem. I. Am. Chem. Soc. 1988. 110. 1539. (d) Srebtik. M.: Ramachandran. P. V.: Brown. II. C. J. Org. Chem. 1988. 53.2916. (L) Ramachandran. P. V.: Teodorovic, $A$. V.: Rangaishemvi. M. V.: I3rown. H. C.. Hid. 1992. $57.237 \%$

2. (a) Cha. J. S.: Kinn. E. J.: K¥on. O. O.: Kim. J. M. Bull. Konem Chem. Soc. 1994. 15. 1033. (b) /dem. Sinhen 1995. 331. (c) datem. Bull. Korem (hem. Soc, 1996. 77.50.

3. (a) Cha J. S.: Kim. Г. J.: Kwon, O, ( .: Kwon, S. Y.: Sco. W. W.: Chang. S. W. Org. Prep. Proced Int 1905. 27. 541 (b) Cha. I. S.: Kim. I:. J.: Kwon. 0. (). Kim. J. M. Bull Korean (hem. Soc. 1995. 16. 691

4. All glasswarc used was dricd thoroughly in an oven. assembled hot. and cooled under a steam of dry jitrogen prior to usc. All ratactions and manipulations of air- and moisture-sensitive materials were carried out using standard technicues for handling aij-sensitive materials. 'Tetrahydroluran (THF) was dried over sodium-benzoplsemone kelyl and distilled. All liquid materials were tratistorred by using hypodermic syringes.

5. The following competitive reduction between hexanal and 2heptanone is representative. In a $50-\mathrm{ml}$. round-bottomed flask was placed $5.0 \mathrm{mmol}$ each compound solution $(2.0 \mathrm{M})$ in $1 \mathrm{lll}$ : followed by $0.60 \mathrm{ml}$ ol $\mathrm{f}$-lridecane ats an intemal standard. The llask was kept at $25^{\circ} \mathrm{C}$ if a water bath. To this flask was added 6.0 mL of a $1.0 \mathrm{M}$ solution of $1 \mathrm{pc}_{2} \mathrm{BOC}_{\text {les }}$ in THF (6.0 mmol) with vigorous stirring. The reaction mixture was stired at $25^{\circ} \mathrm{C}$ for 24 h. It was then hydrolyzed with $2 \mathrm{ml}$ of $2 \mathrm{~N} \mathrm{Nal}$. II, and then the organoborane was oxidized with $\mathrm{I} \mathrm{mL}$, of $30 \% \mathrm{O} \mathrm{I}_{2}()_{2}$ for $2 \mathrm{~h}$ al room temperature with stiming. Alter oxidation. the ayueous layer was saturated with $\mathrm{K}_{2} \mathrm{CO}_{3}$ and the separated organic layer was dricd over anlydrous $\mathrm{MgSO}_{4}$. GC analysis of the $\mathrm{TH} H$ layer showed a $100 \%$ yicld of 1 -hexanol and a $100 \%$ vicld of recovered 2-heptanone. indicating no presence of 2 -heptanol. 